\title{
Biological Control of Pink Bollworm Pectinophora gossypiella (Saunders) by Bacillus cereus MA7
}

\author{
Salem A Mahfouz ${ }^{1 *}$ and Adel A Abou El-Ela ${ }^{2}$
}

${ }^{1}$ Microbiology Dept., Fac. Agric., Fayoum Univ., Egypt

${ }^{2}$ Zoology Dept., Fac. Sci., Fayoum, Egypt

\begin{abstract}
The present study describes the insecticidal potentiality of spore-crystal complex and supernatant of Bacillus cereus strain isolated from dead or moribund pink bollworm. Three isolates of actinomycetes, two gram-negative and two spore-forming bacteria were isolated from the larvae and complete identification was performed for the most effective one. The toxicity of the two preparations was evaluated against $1^{\text {st }}$ and $4^{\text {th }}$ instars larvae of $P$. gossypiella. The $\mathrm{LC}_{50 \mathrm{~s}}$ of $B$. cereus spore-crystals for the tested insect were; $88.5,200 \mu \mathrm{g} / \mathrm{g}$, respectively. While, $\mathrm{LC}_{50 \mathrm{~s}}$ of the supernatant were; 284.8 and $277.5 \mu \mathrm{l} / \mathrm{g}$, respectively. The retarding effects of the two preparations were slightly extended to the pupa and adult stages.
\end{abstract}

Keywords: Biological control; Pink bollworm; Bacillus cereus; Sporecrystal complex; Supernatant; Mortality

\section{Introduction}

The society is faced with the problem of increasing the use of pesticides to control pests in the absence of their predators or bioagents. On the other hand, there is an ever-increasing need for food and especially for improved crop production in the developing countries. Therefore, some of the methods currently used to achieve higher yields, especially by pest and disease control, are environmentally undesirable. Also, manufacturing and application of conventional chemical pesticides has direct and indirect risks to man [1]. Besides, many insects have developed marked or complete resistance to many chemical insecticides [2,3]. During the last few years, biologists have turned their attention to the possibility of using other organisms as biological control agents, and the microbiologists contributing in the development of the efficacy of microbial substances (bacteria, fungi, virus and protozoa) for the control of many insect pests. Although a 100 or so bacteria cause diseases of insects [4], only few are used commercially as control agents. Some bacteria have been isolated from soil, insect habitats $[5,6]$, insect larvae $[7,8]$ or stored products [9]. In their work on the application of Bacillus species in control of Meloidogyne javanica (Treub) chitwood on Cowpea and Mash bean, Dawar et al. [10] reported that the application of $B$. cereus cell suspension reduced the hatching of the eggs and caused a mortality reaching more than $50 \%$. When B. cereus strains; Ae10 and $\mathrm{Cx} 5$ were used for the bio-control of mosquitoes, Luxananil et al. [11] concluded that the results raised the possibility that $B$. cereus strains may be applicable as new mosquito larvicide host cells with long persistence. They also added that oral feeding to mice did not lead to abnormal symptoms, and negative results were obtained in a rabbit skin irritation assay.

Diverse population of aerobic endospore-forming bacteria occurs in agricultural fields and may directly or indirectly contribute to crop productivity. $B$. thuringiensis is very well-known as a bio-control agent against many insects especially its crystal protein $[12,13]$. Despite most species of Bacillus are harmless saprophytes, two species viz., $B$. thuringiensis and $B$. cereus are considered medically and environmentally important especially in field of controlling some plant insects [14]. Currently, pathogenicity of $B$. cereus, for example, mainly relies on the secretion of a wide array of toxins and enzymes [15]. Although B. cereus UW85 was identified for its ability to suppress alfalfa damping-off caused by Phytophthra medicaginis [16], it also suppresses other diseases of cucumber, peanuts, tobacco and tomato which some of them are caused by insects [17].

The present study was initiated to determine the pathogenic bacteria associated with the pink bollworm P. gossypiella (Saunders) which is the most important insect pest of cotton in Egypt. This insect causes considerable damage to both quality and quantity of cotton staple in spite of the wide spread use of insecticides to control it.

\section{Materials and Methods}

\section{Collecting larvae}

Green cotton bolls were collected from fields at Fayoum Governorate, Egypt during September and October, 2009. The bolls were dissected and inspected thoroughly for infestation with $P$. gossypiella larvae. Active and healthy larvae were collected and reared at $27 \pm 2^{\circ} \mathrm{C}$ and $65 \pm 3 \%$ relative humidity $(\mathrm{RH})$, on a formulated diet previously described by AbdEl-Hafez et al. [18]. Emerging moths were kept under the above mentioned laboratory conditions and provided with $10 \%$ sucrose solution. After mating, female moths were allowed to lay their eggs in glass chimney cages covered with muslin. The dead or moribund larvae were stored solely in sterilized tightly closed vials at $4^{\circ} \mathrm{C}$ in refrigerator until needed.

\section{Bacterial isolation techniques}

In order to reveal any microorganisms associated with the subjected insects, each of the refrigerated individuals was examined through 24$72 \mathrm{hrs}$ from the time of storage under aseptic conditions. The larvae were surface sterilized by dipping in $2 \%$ sodium hypochlorite for 3-5 minutes, then passed through five separate washing with sterile distilled water [19]. For insuring the appropriate surface sterilization,

*Corresponding author: Salem A Mahfouz, Microbiology Dept., Fac. Agric., Fayoum Univ., Egypt, E-mail: salmahfouze@yahoo.com

Received December 06, 2010; Accepted March 29, 2011; Published March 31 2011

Citation: Mahfouz SA, Abou El-Ela AA (2011) Biological Control of Pink Bollworm Pectinophora gossypiella (Saunders) by Bacillus cereus MA7. J Microbial Biochem Technol 3: 030-032. doi:10.4172/1948-5948.1000047

Copyright: (c) 2011 Mahfouz SA, et al. This is an open-access article distributed under the terms of the Creative Commons Attribution License, which permits unrestricted use, distribution, and reproduction in any medium, provided the original author and source are credited. 
checks were made by spreading the last washing solution on nutrient agar. Sterilized larvae were dried up between two sterilized filter papers (Whattman No1). After that, these larvae were transferred aseptically into a sterile mortar and macerated with a sterile pestle, then diluted and plated on nutrient agar for growth incubating them at $27^{\circ} \mathrm{C}$ for $24-$ $48 \mathrm{hrs}$. Some dishes were incubated for extra-time in order to check the presence of slow growing microorganisms. Incubated plates were inspected daily to observe the bacterial colonies' growth that were then purified, used by following Koch's postulates and stored on slants of the desired artificial media at $4^{\circ} \mathrm{C}$. The isolates were cultured periodically until they had been used in the subsequent experiments. Healthy larvae were subjected to the same procedures of isolation for obtaining the expected dormant pathogens.

\section{Identification of the bacterial isolates}

The isolates were taken and sub-cultured till full purification. Gram staining was used to differentiate between the isolates. For spore-forming bacteria, the diluted tubes were pasteurized at $63^{\circ} \mathrm{C}$. All bacterial isolates were tested for their toxicity on larvae and the most effective one was subjected to further identification to the species level according to [20] Krieg and the use of API50-CHB (France Biomeric).

\section{Preparation of bacterial cell-free supernatant}

The bacterial species were grown on nutrient agar at $27^{\circ} \mathrm{C}$. Spores and crystals were obtained by washing the old slant of each species [21, 22] then, inoculating a $100 \mathrm{ml}$ of nutrient broth in a $250 \mathrm{ml}$ Erlenmeyer flask with each suspension. The inoculated broth was incubated in a shaking-incubator at $30^{\circ} \mathrm{C}$ and $200 \mathrm{rpm}$ for $24 \mathrm{hrs}$, after which the entire culture was used as an inoculum for 1 liter of nutrient broth in a $2800 \mathrm{ml}$ flask. The broth was incubated at $30^{\circ} \mathrm{C}$ and $200 \mathrm{rpm}$ until the bacteria sporulated and lysed releasing crystals and spores into the medium.

Cells, spores and crystals were removed by centrifugation in a cooling centrifuge at approximately $20,000 \mathrm{~g}$ for $30 \mathrm{~min}$ at $4^{\circ} \mathrm{C}$. The supernatant which contained the exotoxin was then examined for its thermal stability and stored at $4^{\circ} \mathrm{C}$ until needed. The pelleted spores and crystals were collected and centrifuged again then freeze-dried [23].

\section{Toxicity test and bioassays}

The stock solutions of spore-crystals were prepared by suspending $15 \mathrm{mg}$ of spore-crystal powder in $25 \mathrm{ml}$ saline buffer containing $1 \%$ Tween 80. Concentrations of 50, 100, 200, 400 and $800 \mu \mathrm{g} / \mathrm{g}$ diet were prepared and tested for their toxicity to $1^{\text {st }} \& 4^{\text {th }}$ instars larvae of pink bollworm P. gossypiella (Saunders). An aliquot of each suspension was added to a plastic cup containing $300 \mathrm{~g}$ of formulated diet and mixed at high speed for 2 min with a malt mixer. A diet treated with each concentration was dispensed into fifty $(30 \mathrm{ml})$ anther plastic cups. Another fifty cups containing the formulated diet to which buffered saline solution was added were used as control. The diet was stored at room temperature overnight to solidify, two pink bollworm neonate larvae were placed in each cup and the cups were incubated at $27^{\circ} \mathrm{C}$ and $65 \% \mathrm{RH}$. Larval mortality was recorded after $48 \mathrm{hrs}$ of incubation. Mortality was calculated according to Abbott's formula [24]:

$$
\text { Corrected mortality }(\%)=\frac{P-P_{0}}{100-P_{0}} \times 100
$$

Where $\mathrm{P}$ is the percent mortality of treated larvae, $\mathrm{P}_{0}$ is the percent mortality of the untreated control.

The toxicity of the supernatant containing the thermostable exotoxin (TET) for the pink bollworm was tested by adding supernatant of bacterial species, heated at $121^{\circ} \mathrm{C}$, to $300 \mathrm{~g}$ of formulated diet to obtain serial concentrations of supernatant; 50, 100, 200, 400 and 800 $\mu \mathrm{l}$ of the supernatant, respectively. The diet and supernatant were mixed thoroughly for $2 \mathrm{~min}$ with a malt mixer and dispensed into fifty $(30 \mathrm{ml})$ plastic cups. Pink bollworm neonate larvae were placed in each cup (2 larvae/cup) and incubated at $27^{\circ} \mathrm{C}$ and $65 \% \mathrm{RH}$. Larval mortality was recorded after $48 \mathrm{hrs}$ of incubation. The test was replicated four times and the percentages of pupation and adult emergence were recorded.

\section{Results and Discussion}

\section{Identification of the isolated entomogenous microorganisms}

A total of 8 internal bacteria, isolated from naturally infested larvae of pink bollworm were; 3 actinomycetes, 2gram-negative short rods bacteria and 3 spore-forming. The three spore-forming isolates related to the genus Bacillus and the most effective one, used in this study, was characterized as Bacillus cereus MA7. In the preliminary bioassays, the three bacterial isolates were assayed for pathogenesis against neonate larvae of $P$. gossypiella. Only one isolate of bacteria increase mortality among neonate larvae when all treatments were compared with the control using Abbott's formula. Mortality in these treatments ranged between 20 to $100 \%$ and the bacterial strain which was readily reisolated from dead larvae was confirmed to be B. cereus MA7.

\section{Toxicity of B. cereus MA7 spore-crystal complex}

In the present study, the two insect larvae were markedly affected with $B$. cereus spore-crystal. The $\mathrm{LC}_{50 \mathrm{~s}}$ were; 88.5 ( $1^{\text {st }}$ instars larvae $)$ and 200 ( $^{\text {th }}$ instars larvae) Table (2). The toxic action of $B$. cereus sporecrystal complex increased with the increase of concentration level to reach $100 \%$ for the $1^{\text {st }}$ instars and 77.5 for the $4^{\text {th }}$ instars at $800 \mu \mathrm{g} / \mathrm{g}$, respectively with a gradual increase for both instars. (Tables 1 and 2 ). Also, the relative susceptibility of the $4^{\text {th }}$ instars larvae to the $1^{\text {st }}$ instars of the pink bollworm reached 2.25 times only. These results are in agreement with the findings of Mohd-Salleh and Lewis [22] who reported the similar effect of spore-crystal complex of $B$. thuringiensis against corn insects.

\section{Toxicity of $B$. cereus MA7 supernatant containing TET}

Sterile supernatant of $B$. cereus showed toxic activity against the pink

\begin{tabular}{|c|c|c|c|c|c|c|}
\hline \multirow{2}{*}{$\begin{array}{l}\text { Treated } \\
\text { instars } \\
\text { larvae }\end{array}$} & \multirow[b]{2}{*}{$\begin{array}{l}\text { Concentration } \\
(\mu \mathrm{g} / \mathrm{g})\end{array}$} & \multicolumn{5}{|c|}{$\%$ Larval mortality } \\
\hline & & $\begin{array}{l}\text { Mortality } \\
\text { of tested } \\
\text { larvae }\end{array}$ & $\begin{array}{l}\text { Total } \\
\text { larval } \\
\text { mortality }\end{array}$ & $\begin{array}{l}\% \\
\text { pupation }\end{array}$ & $\begin{array}{l}\text { Pupal } \\
\text { mortality }\end{array}$ & $\begin{array}{l}\% \text { adult } \\
\text { emergence }\end{array}$ \\
\hline \multirow{5}{*}{$\begin{array}{l}1^{\text {st }} \text { instars } \\
\text { larvae }\end{array}$} & 50 & 37.0 & 49.8 & 50.2 & 6.7 & 45.5 \\
\hline & 100 & 61.5 & 76.2 & 23.8 & 6.5 & 17.3 \\
\hline & 200 & 85.0 & 91.5 & 8.5 & 3.0 & 5.5 \\
\hline & 400 & 93.5 & 98.6 & 1.4 & 1.4 & 0.0 \\
\hline & 800 & 100 & 100 & 0.0 & 0.0 & 0.0 \\
\hline \multirow{5}{*}{$\begin{array}{l}4^{\text {th }} \text { instars } \\
\text { larvae }\end{array}$} & 50 & 22.6 & 29.5 & 70.5 & 5.3 & 65.2 \\
\hline & 100 & 41.4 & 46.0 & 54.0 & 6.0 & 48.0 \\
\hline & 200 & 50.0 & 53.8 & 46.5 & 6.5 & 39.7 \\
\hline & 400 & 62.8 & 66.5 & 33.5 & 6.8 & 27.5 \\
\hline & 800 & 77.5 & 80.4 & 19.6 & 4.6 & 15.0 \\
\hline
\end{tabular}

N.B. Percentages of larval mortality were corrected using Abbot's formula [24]

Table 1: Effect of spore-crystal complex of B. cereus MA7 as tested against $1^{\text {st }}$ and $4^{\text {th }}$ instars larvae of the pink bollworm P. gossypiella (Saunders).

\begin{tabular}{|l|l|l|l|l|}
\hline $\begin{array}{l}\text { Treated instars } \\
\text { larvae }\end{array}$ & $\begin{array}{l}\mathrm{LC}_{50} \\
\mu \mathrm{g} / \mathrm{g} \text { of diet }\end{array}$ & Slope & $\begin{array}{l}95 \% \text { confidence } \\
\text { interval } / \mu \mathrm{g} / \mathrm{g}\end{array}$ & $\begin{array}{l}\text { Relative } \\
\text { susceptibility }\end{array}$ \\
\hline $1^{\text {st }}$ instars larvae & 88.5 & $5.84 \pm 0.347$ & $75.5-98.6$ & 2.25 \\
\hline $4^{\text {th }}$ instars larvae & 200 & $3.45 \pm 0.38$ & $189.4-213$ & 1.30 \\
\hline
\end{tabular}

Table 2: Potencies of spore-crystal complex of B. cereus MA7 as tested against neonate larvae of the pink bollworm P. gossypiella (Saunders). 


\begin{tabular}{|c|c|c|c|c|c|c|}
\hline \multirow[b]{2}{*}{$\begin{array}{l}\text { Treated } \\
\text { instars } \\
\text { larvae }\end{array}$} & \multirow[b]{2}{*}{$\begin{array}{l}\text { Concentration } \\
(\mu \mathrm{l} / \mathrm{g})\end{array}$} & \multicolumn{5}{|c|}{$\%$ Larval mortality } \\
\hline & & \begin{tabular}{|l} 
Mortality \\
of tested \\
larvae
\end{tabular} & \begin{tabular}{|l} 
Total \\
larval \\
mortality
\end{tabular} & $\begin{array}{l}\% \\
\text { pupation }\end{array}$ & $\begin{array}{l}\text { Pupal } \\
\text { mortality }\end{array}$ & \begin{tabular}{|l}
$\%$ adult \\
emergence
\end{tabular} \\
\hline \multirow{5}{*}{$\begin{array}{l}1^{\text {st instars }} \\
\text { larvae }\end{array}$} & 50 & 82.5 & 100 & 0.0 & 0.0 & 0.0 \\
\hline & 100 & 75.5 & 80.4 & 19.6 & 6.6 & 13.0 \\
\hline & 200 & 63.8 & 68.6 & 31.4 & 5.5 & 26.0 \\
\hline & 400 & 44.6 & 50.0 & 50.0 & 6.0 & 44.0 \\
\hline & 800 & 31.7 & 36.5 & 63.5 & 4.4 & 59.5 \\
\hline \multirow{5}{*}{$\begin{array}{l}4^{\text {th }} \\
\text { instars } \\
\text { larvae }\end{array}$} & 50 & 80.9 & 83.5 & 16.5 & 4.8 & 11.7 \\
\hline & 100 & 66.5 & 70.0 & 30.0 & 4.6 & 25.4 \\
\hline & 200 & 54.6 & 56.8 & 43.2 & 5.3 & 38.0 \\
\hline & 400 & 40.4 & 42.4 & 57.6 & 3.6 & 54.0 \\
\hline & 800 & 29.8 & 31.5 & 68.5 & 4.0 & 64.5 \\
\hline
\end{tabular}

N.B. Percentages of larval mortality were corrected using Abbot's formula [24].

Table 3: Effect of different concentrations of $B$. cereus MA7 supernatant as against the neonate larvae of the pink bollworm P. gossypiella (Saunders).

\begin{tabular}{|l|l|l|l|l|}
\hline $\begin{array}{l}\text { Treated instars } \\
\text { larvae }\end{array}$ & $\begin{array}{l}\mathrm{LC}_{50} \\
\mu \mathrm{l} / \mathrm{g} \text { of diet }\end{array}$ & Slope & $\begin{array}{l}95 \% \text { confidence } \\
\text { interval } / \mu \mathrm{g} / \mathrm{g}\end{array}$ & Relative susceptibility \\
\hline $1^{\text {st }}$ instars larvae & 284.8 & 4.92 & $275.6-292.4$ & 1.050 \\
\hline $4^{\text {th }}$ instars larvae & 277.5 & 4.56 & $283.7-295.6$ & 1.026 \\
\hline
\end{tabular}

Table 4: Potencies of B. cereus MA7 supernatant as tested against neonate larvae of the pink bollworm P. gossypiella (Saunders).

bollworm (Table 3). The presence or absence of TET in this supernatant was confirmed in these tests where the mortality percentages of the tested insect were correlated negatively with the increase of concentration level of bacterial supernatant. The mortality percentage was higher at lower concentration; 82.5 for $1^{\text {st }}$ instars and 80.9 for the $4^{\text {th }}$ instars. While, the lower percentages were recorded at higher concentrations where it was 31.7 and 29.8 for $1^{\text {st }}$ and $4^{\text {th }}$ instars, respectively. This phenomenon has been substantiated with other lepidopterous insects and could be attributed to feeding deterrence associated with TETs [22]. P. gossypiella was found to have low sensitivity with regard to $\mathrm{LC}_{50}$ where it showed 284.8 and 277.5 for the $1^{\text {st }}$ and $4^{\text {th }}$ instars, respectively (Table 4). It's worth mentioning that the spore-crystal complex was more effective than the supernatant containing TETs. The general phenomenon is in an agreement with the findings of Feng et al. [25] and Abou El-Ela [8]. The present investigation also showed that the supernatant of $B$. cereus containing TET killed more than $80 \%$ of first instar larvae for the tested insect and these results disagree with what was reported by Raun et al. [26]. who showed that TET had only a limited effect on the tested corn borer insect.

\section{The retarding effect}

The retarding effect of spore-crystal complex or supernatant has been kept in the survivors from the treatments. Thus, the percentages of pupation and adult emergence were negatively correlated with the increase of spore-crystal concentration and positively with the increase in the concentration of the supernatant. The obtained results are in parallel with the findings of Azab [27].

Finally, it appears that B. cereus supernatant or spore-crystal complex may be used as a biological control agent for the tested insect although further study is still needed regarding the chemical identification of the metabolites as well as other host insects to be tested.

\section{References}

1. Mazyad SA, El-Serougi AOM, Morsy TA (1990) The efficacy of the volatile oils of three plants for controlling Lucilia sericata. J Egypt Soc Parasitol 29: 91-100.

2. WHO (1970) Insecticides resistance and vector control. Tech Report Ser No 443, 2779 Wld HIth Organ Geneva, Switzerland

3. Brown AWA, Pal R (1977) Insecticide resistance in Arthropods. Bull Wld Hlth Organ.,Geneva, Switzerland.
4. Contwell GE (1974) Insect diseases. Vols I \& II, Marcel Decker Inc New York.

5. Ohba M, Aizawa K, Furusawa S (1979) Distribution of Bacillus thuringiensis serotype in Ehine perfectre Japan. Appl Entomol Zool 14: 340-345.

6. McSpadden Gardner BB (2004) Ecology of Bacillus and Paenbacillus spp in agricultural systems. Phytopathol 94: 1252-1258.

7. Krigg-Von NR, Huger AM, Longenbrugh GA, Shneter W (1983) Bacillus thuringiensis var. tenerbrionsis ein eur genuber larven von Coleopteren wirksamer pathotyp. Z Angew Entwick Lungesgesch 96:00-508.

8. Abou El-Ela AA (1996) Pathogenic studies on some Lepidoptera insects. M.Sc Thesis Fac Sci Cairo Univ Egypt.

9. Kares AE (1991) Effect of mixture of Bacillus thuringiensis (Berliner) and chemical insecticides against larvae of pink bollworm Pectinophora gossypiella (Lepidoptera: Gelechiidae). Egypt J Biol Pest Cont 1: 15-23.

10. Dawar S, Tariq M, Zaki MJ (2008) Application of Bacillus species in control of Meloidogyne javanica (Treub) Chitwood on cowpea and Mash bean. Pak J Bot 40: 439-444.

11. Luxananil P, Atomi $\mathrm{H}$, Chaisri U, Tungpradabkul S, Panyim S, et al. (2002) A fundamental study on bio-control of environmental mosquito problems: Genetic and biological characterization of potentially novel insecticide bacteria. J Environ Biotechnol 2: 47-52.

12. Hofte H, Whiteley HR (1989) Insecticidal crystal proteins of Bacillus thuringiensis. Microbiol Rev 53: 242-255.

13. Schnepf E, Crickmore N, Van Rie J, Lereclus D, Baum J, et al. (1998) Bacillus thurigiensis and its pesticidal crystal proteins. Microbio Mol Biol 62: 775-806.

14. Gray EJ, Lee KD, Souleimanov AM, Falco MRD, Zhou XALY, et al. (2006) A novel bacteriocin, thuricin 17 , produced by plant growth promoting rhizobacteria straut BT NEB17: isolation and identification. J Appl Microbiol 100: 545-554.

15. Senesi S, Ghelardi E (2010) Production, secretion and biological activity of Bacillus cereus enterotoxins. Toxins 2: 1690-1703.

16. Handelsman J, Raffel S, Mester EH, Wunderlich L, Grau CR (1990) Biological control of dampinf-off of alfalfa seedlings with Bacillus cereus UW85. Appl Environ Microbiol 56: 713-718.

17. Smith KP, Havey MJ, Handelsman J (1993) Suppression of cottony leak of cucumber with Bacillus cereus strain UW85. Plant Dis 77: 139-142.

18. Abdel-Hafez A, Metwally AG, Saleh MRA (1982) Rearing of the pink bollworm Pectinophora gossypiella (Saunder) on kidney bean diet (Lepidoptera: Gelechiidae). Res Bull Fac Agric Zagazig Univ 576, 10pp.

19. Crecchio G, Stotzky G (2001) Biodegradation and insecticidal activity of the toxin from Bacillus thuringiensis subsp. Kurstak bound on complexes of montmorrillonite humic acid-hydroxy polymers. J Soil Biol \& Biochem 33: 573581.

20. Krieg NR (1994) Bergey's Manual of Systematic Bacteriology. The Williams \& Wilkins Co Baltimore.

21. Dulmage HT, Boening OP, Rehnborc CS, Hansen GD (1971) A proposed standardized bioassay for formulation of Bacillus thuringiensis based on the international unit. J Inverteb Pathol 18: 240-245.

22. Mohd-Salleh MB, Lewis LC (1983) Comparative effects of spore-crysta complexes and thermostable exotoxins of six subspecies of Bacillus thurigiensis against Ostrinia nubilalis (Lepidoptera: Pyralidae). J Invertebr Pathol 41: 336340.

23. Dulmage HT, Correa JA, Martinez AJ (1970) Co-precipitation with lactose as a mean of recovering the spore-crystal complex of Bacillus thuringiensis. $J$ Inverteb Pathol15: 15-20.

24. Abbot WS (1925)A method of computing the effectiveness of insecticides. J Econ Entomol 18: 265-267.

25. Feng Z, Carruthers RI, Roberts DW, Robson DS (1985) Age-specific dose mortality effects of Beauveria bassiana (Deutomycotina hyphomycetes) on the European corn borer Ostrinia nubilalis ( Lepidoptera: Pyralidae). J Inverteb Pathol 46: 258-264.

26. Raun ES, Sutter GR, Revelo MA (1966) Ecological factors affecting the pathogenicity of Bacillus thuringiensis var. thuringiensis to the European corn borer and fall army worm. J Invertebr Pathol 8: 465-375.

27. Azab AMH (2003) Susceptibility of different stages of the black cutworm Agrotis ipislon (Lepidoptera: Noctuidae) to the infection with the bacteria Bacillus thuringiensis. Egypt J Appl Sci 10: 382-391. 